Article

\title{
A Hybrid Material Combined Copper Oxide with Graphene for an Oxygen Reduction Reaction in an Alkaline Medium
}

\author{
Jiemei Yu ${ }^{1,2}$, Taizhong Huang ${ }^{1}$, Zhankun Jiang ${ }^{1}$, Min Sun ${ }^{1, *}$ and Chengchun Tang ${ }^{2, *}$ \\ 1 School of Chemistry and Chemical Engineering, University of Jinan, 336 West Nanxinzhuang Road, Jinan \\ 250022, China; chm_yujm@ujn.edu.cn (J.Y.); chm_huangtz@ujn.edu.cn (T.H.); chm_jiangzk@ujn.edu.cn (Z.J.) \\ 2 School of Materials Science and Engineering, Hebei University of Technology, 8 of First Road of Dingzigu, \\ Hongqiao District, Tianjin 300130, China \\ * Correspondence: chm_sunm@ujn.edu.cn (M.S.); tangcc@hebut.edu.cn (C.T.); \\ Tel.: +86-(0)-15053123169 (M.S.); Fax: 0531-89736983 (M.S.)
}

Received: 20 December 2018; Accepted: 22 January 2019; Published: 26 January 2019

\begin{abstract}
In this work, an electrode material based on CuO nanoparticles (NPs)/graphene (G) is developed for ORR in alkaline medium. According to the characterization of scanning electron microscope and transmission electron microscope, $\mathrm{CuO}$ NPs are uniformly distributed on the wrinkled $\mathrm{G}$ sheets. The X-ray diffraction test reveals that the phase of $\mathrm{CuO}$ is monoclinic. The $\mathrm{CuO} / \mathrm{G}$ hybrid electrode exhibits a positive onset potential $(0.8 \mathrm{~V})$, high cathodic current density $(3.79 \times$ $10^{-5} \mathrm{~mA} / \mathrm{cm}^{2}$ ) and high electron transfer number (four-electron from $\mathrm{O}_{2}$ to $\mathrm{H}_{2} \mathrm{O}$ ) for ORR in alkaline media. Compared with commercial $\mathrm{Pt} / \mathrm{C}$ electrocatalyst, the $\mathrm{CuO} / \mathrm{G}$ electrode also shows superior fuel durability. The high electrocatalytic activity and durability are attribute to the strong coupling between $\mathrm{CuO}$ NPs and G nanosheets.
\end{abstract}

Keywords: copper oxide; graphene; electrocatalyst; oxygen reduction reaction; alkaline medium

\section{Introduction}

Our modern societies have to stand in a transition line from traditional fossil energy to sustainable clean energy, with the increasing demands for environmental and energy sustainability [1,2]. In 1839, the first fuel cell was developed which can transform chemical energy directly into electrical energy [3]. Ever since then, more and more attentions have concentrated on this renewable energy technologies due to the excellent energy conversion and relatively high power density [4]. In the development of fuel cells, a considerable number of studies focused on improving its oxygen reduction reaction (ORR) performance [5-8]. Triggered by the high cost and low tolerance to fuel crossover of Pt-based cathodes, a large number of researches have been conducted on seeking abundant and cheap substituted catalysts for an efficient ORR under fuel-cell working conditions [9]. Among many catalysts developed over the past decades, various non-noble metal catalysts have been considered [10], these include mixed valence oxides of transition metals, nitrogen containing and functionalized carbon materials [11-13].

Among the transition metal catalysts, $\mathrm{Cu}[14], \mathrm{Co}[15]$, and Fe [16,17] are the widely studied materials, particularly, copper based catalysts have been widely investigated to catalyze the ORR due to its good durability, high catalytic activity and environmentally friendliness in alkaline medium [18,19]. Gewirth and co-worker [20] synthesized a Cu-based molecular catalyst with enhanced electrocatalytic properties for oxygen reduction reaction. Meanwhile, Wang et al. [21] designed the material of $\mathrm{Cu}$-complex-hybrid anchored on reduced graphene oxide $(\mathrm{rGO})$ sheets, which has the high exchanged electron density during ORR process. High electrocatalytic activities of $\mathrm{Cu}_{\mathrm{x}} \mathrm{Co}_{3-\mathrm{x}} \mathrm{O}_{4}$ for the ORR have also been reported by Koninck et al. [22,23]. Conchi et al. [24] reported a new $\mathrm{Cu} / \mathrm{rGO}$ catalyst with 
the excellent ORR activity in terms of high current densities and long-term stability. Blanford et al. [25] attached $\mathrm{Cu}$-containing multi-Cu oxidases (fungal laccases) to a substrate-like anthracene-modified pyrolytic graphite. It was found that, the strong adsorption of laccase on anthracene-based units make the laccase more stable on the modified graphite than that on the untreated graphite.

In this study, the catalyst of $\mathrm{CuO}$ nanoparticles (NPs) anchored on graphene nanosheets (donated as $\mathrm{CuO} / \mathrm{G}$ ) was synthesized by an efficient and facile hydrothermal method. The graphene oxide was reduced simultaneously with the growth of $\mathrm{CuO} N P s$ on graphene oxide. The obtained $\mathrm{CuO} / \mathrm{G}$ hybrid was used as a new electrode material for ORR. The electrocatalytic activity of $\mathrm{CuO} / \mathrm{G}$ was evaluated, using $\mathrm{CuO}$ and $\mathrm{G}$ as references.

\section{Results and Discussion}

\section{Structural Characterization}

The morphology and microstructure of our materials were characterized by SEM (scanning electron microscopy), TEM (transmission electron microscopy), and HRTEM (high resolution TEM). In Figure 1a, CuO NPs aggregated to a certain extent. While in Figure 1b, CuO NPs dispersed on the surface of $\mathrm{G}$ uniformly, and $\mathrm{G}$ nanosheets serve as the support frame. The catalyst loading per area of $\mathrm{CuO} / \mathrm{G}$ is calculated to be $0.0084 \mathrm{~g} / \mathrm{m}^{2}$. TEM and HRTEM images of our samples are shown in Figure 1c-f. As can be seen in Figure 1c that $\mathrm{CuO}$ NPs are aggregated into large clusters with an average size of about $10 \mathrm{~nm}$, while in Figure 1e, CuO NPs anchor on G nanosheets homogenously, with a small degree of local aggregation and narrow particle size distribution in the range of $6 \sim 8 \mathrm{~nm}$. It reveals that $\mathrm{CuO} N P$ s in $\mathrm{CuO} / \mathrm{G}$ hybrid shows smaller particle size than pure $\mathrm{CuO}$. This indicates the dispersing effect of graphene preventing $\mathrm{CuO} N$ Ps from aggregation. Figure $1 \mathrm{~d}$, f show typical HRTEM images of $\mathrm{CuO} N P s$ in $\mathrm{CuO}$ and $\mathrm{CuO} / \mathrm{G}$, a clear lattice spacing of $0.25 \mathrm{~nm}$ can be observed, which matches well with the (111) plane of monoclinic $\mathrm{CuO}$ [26].

Figure 2a shows the XRD pattern of our samples. The characteristic peaks at $35.50^{\circ}, 38.79^{\circ}$, and $61.54^{\circ}$ match well with the (002), (111), and (113) plans of monoclinic CuO (PDF: 80-1917), respectively, indicating the completely converting from $\mathrm{CuCl}_{2} \cdot 2 \mathrm{H}_{2} \mathrm{O}$ to $\mathrm{CuO}$ NPs during the hydrothermal process. Table 1 shows the lattice constants of $\mathrm{CuO}$ and $\mathrm{CuO} / \mathrm{G}$, which consistent well with the results of the previous literature [27].

Table 1. Lattice constants of $\mathrm{CuO}$ and $\mathrm{CuO} / \mathrm{G}$.

\begin{tabular}{cccc}
\hline Sample & $\mathbf{a}$ & $\mathbf{b}$ & $\mathbf{c}$ \\
\hline $\mathrm{CuO}$ & 0.469 & 0.343 & 0.513 \\
$\mathrm{CuO} / \mathrm{G}$ & 0.469 & 0.342 & 0.513 \\
\hline
\end{tabular}



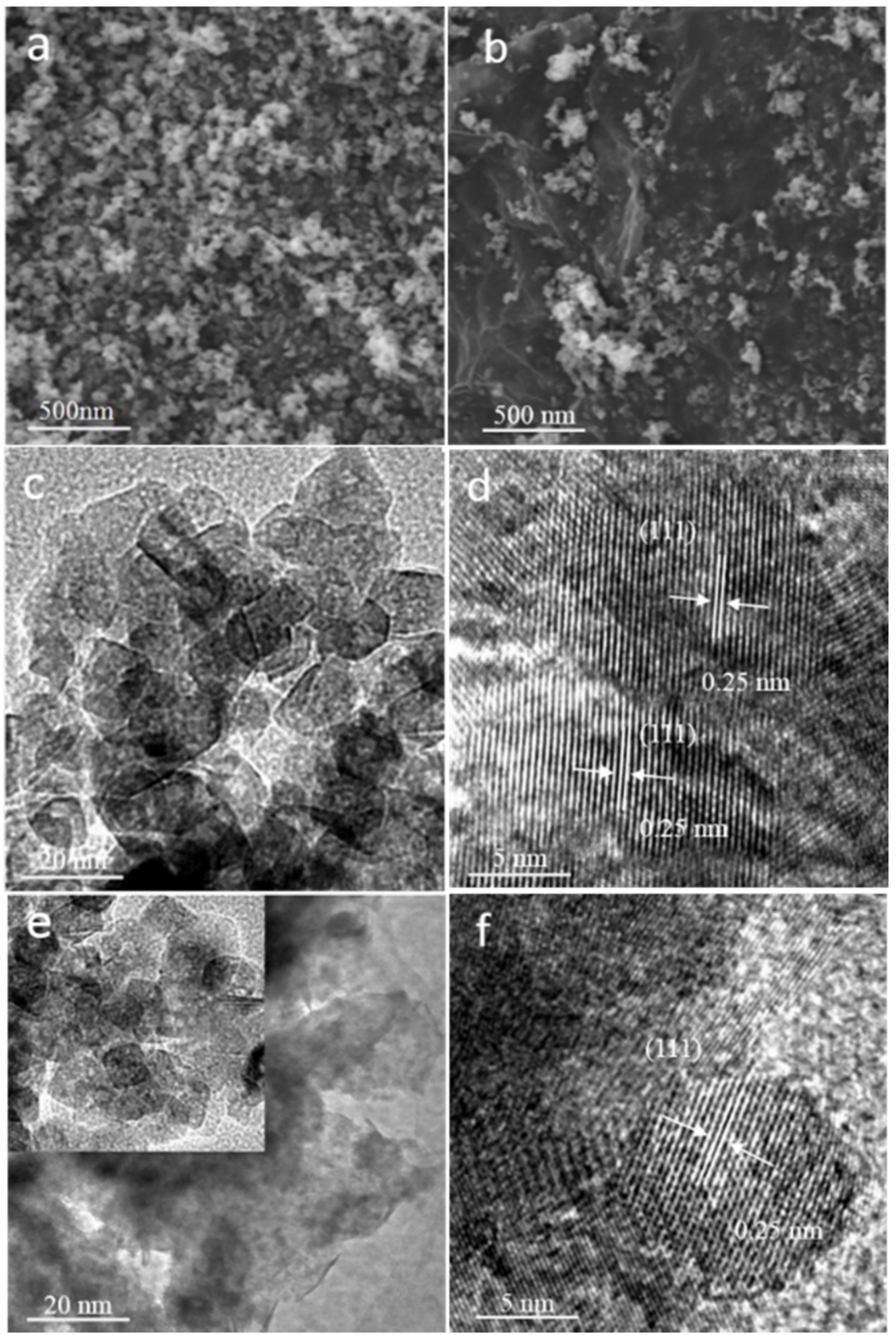

Figure 1. SEM images of (a) $\mathrm{CuO}$ and (b) $\mathrm{CuO} / \mathrm{G}$. TEM images of (c) $\mathrm{CuO}$ and (e) $\mathrm{CuO} / \mathrm{G}$. HRTEM images of (d) $\mathrm{CuO}$ and (f) $\mathrm{CuO} / \mathrm{G}$.

Meanwhile, the crystallite sizes of $\mathrm{CuO}$ and $\mathrm{CuO} / \mathrm{rGO}$ can be calculated from Equation (1) (Supporting Information). The calculations suggest the crystallite size of $\mathrm{CuO}$ and $\mathrm{CuO} / \mathrm{G}$ as $10.7 \mathrm{~nm}$ and $7.1 \mathrm{~nm}$, respectively, consist with the TEM results approximately. The XRD pattern of $\mathrm{CuO} / \mathrm{G}$ also shows a broad peak at $25^{\circ}$, corresponding to the (002) plane of graphene, indicating an effective deoxygenation of GO during the hydrothermal process. However, the graphene peak is very weak, attributes probably to the relatively lower diffraction intensity and the low amount of graphene compared to $\mathrm{CuO}$. The existence of $\mathrm{G}$ in $\mathrm{CuO} / \mathrm{G}$ is also proved by Raman test. In the Raman spectrum, the $G$ band is assigned to the $\mathrm{E}_{2 \mathrm{~g}}$ vibration mode of $\mathrm{sp}^{2}$ domain indicative of the degree of graphitization, while $D$ band represents the structural defects and disordered structures [28]. As shown in Figure $2 b$, the intensity ration of $D$ to $G$ peak $\left(I_{D} / I_{G}\right)$ for CuO/G is 1.0 , the low of $I_{D} / I_{G}$ value implies the removal of oxygenated functional groups during the reduction of graphite oxide into graphene. XPS spectras were recorded to verify the chemical states information of ions of $\mathrm{CuO}$ and 
$\mathrm{CuO} / \mathrm{G}$. As expected, $\mathrm{CuO}$ and $\mathrm{CuO} / \mathrm{G}$ mainly contain $\mathrm{Cu}, \mathrm{O}$ and $\mathrm{C}$ elements (Figure 2c). The $\mathrm{C}$ element of $\mathrm{CuO} / \mathrm{G}$ results from the adventitious element carbon and the $\mathrm{G}$ molecules, while the $\mathrm{C}$ element of $\mathrm{CuO}$ only results from the contamination of the testing environment. The $\mathrm{Cu} 2 \mathrm{p}$ spectrum of $\mathrm{CuO}$ and $\mathrm{CuO} / \mathrm{G}$, as shown in Figure 2d, display double peaks. The peak located at $953.1 \mathrm{eV}$ and $932.2 \mathrm{eV}$ are assigned to $\mathrm{Cu} 2 \mathrm{p} 3 / 2$ and $\mathrm{Cu} 2 \mathrm{p} 1 / 2$ of $\mathrm{Cu}^{2+}$ in $\mathrm{CuO}$, while the corresponding peaks of $\mathrm{Cu} 2 \mathrm{p}$ in $\mathrm{CuO} / \mathrm{G}$ are observed at $957.5 \mathrm{eV}$ and $936.6 \mathrm{eV}$, shifting towards the higher energy region by $4.4 \mathrm{eV}$. Such a shift towards the higher energy region of $\mathrm{Cu} 2 \mathrm{p}$ in $\mathrm{CuO} / \mathrm{G}$ may be attributed to the strong interaction between $\mathrm{CuO}$ and $\mathrm{G}$. This also indicates that the coupling between $\mathrm{CuO}$ and graphene occurs through the $\mathrm{Cu}^{2+}$ species of $\mathrm{CuO}[18,29]$. Figure 2e shows the O 1s XPS spectrum region of $\mathrm{CuO} / \mathrm{G}$ catalyst. The peak located at $530.0 \mathrm{eV}$ and $532.1 \mathrm{eV}$ correspond to $\mathrm{O}^{2-}$ ions of the $\mathrm{Cu}-\mathrm{O}$ species and the oxygen-deficient regions within the $\mathrm{CuO}$ matrix, respectively. The peak located at $533.7 \mathrm{eV}$ is assigned to the $\mathrm{OH}$ group or chemisorbed oxygen on the surface of the catalyst. The presence of the $\mathrm{OH}$ or oxygen groups absorbed onto the surface of $\mathrm{CuO} / \mathrm{G}$ may helpful to enhance its electrocatalytic performance [30]. Figure $2 \mathrm{f}$ shows the high-resolution XPS spectrum of $\mathrm{C} 1 \mathrm{~s}$, which can be deconvoluted into three components as $\mathrm{C}-\mathrm{C}(283.9 \mathrm{eV}), \mathrm{C}-\mathrm{O}(286.1 \mathrm{eV})$ and $\mathrm{C}=\mathrm{O}(287.8 \mathrm{eV})$ species [31], respectively. The C-C is the predominant specie by measuring the relative peak area, indicating the GO has been well deoxygenated during the hydrothermal procedure [32].
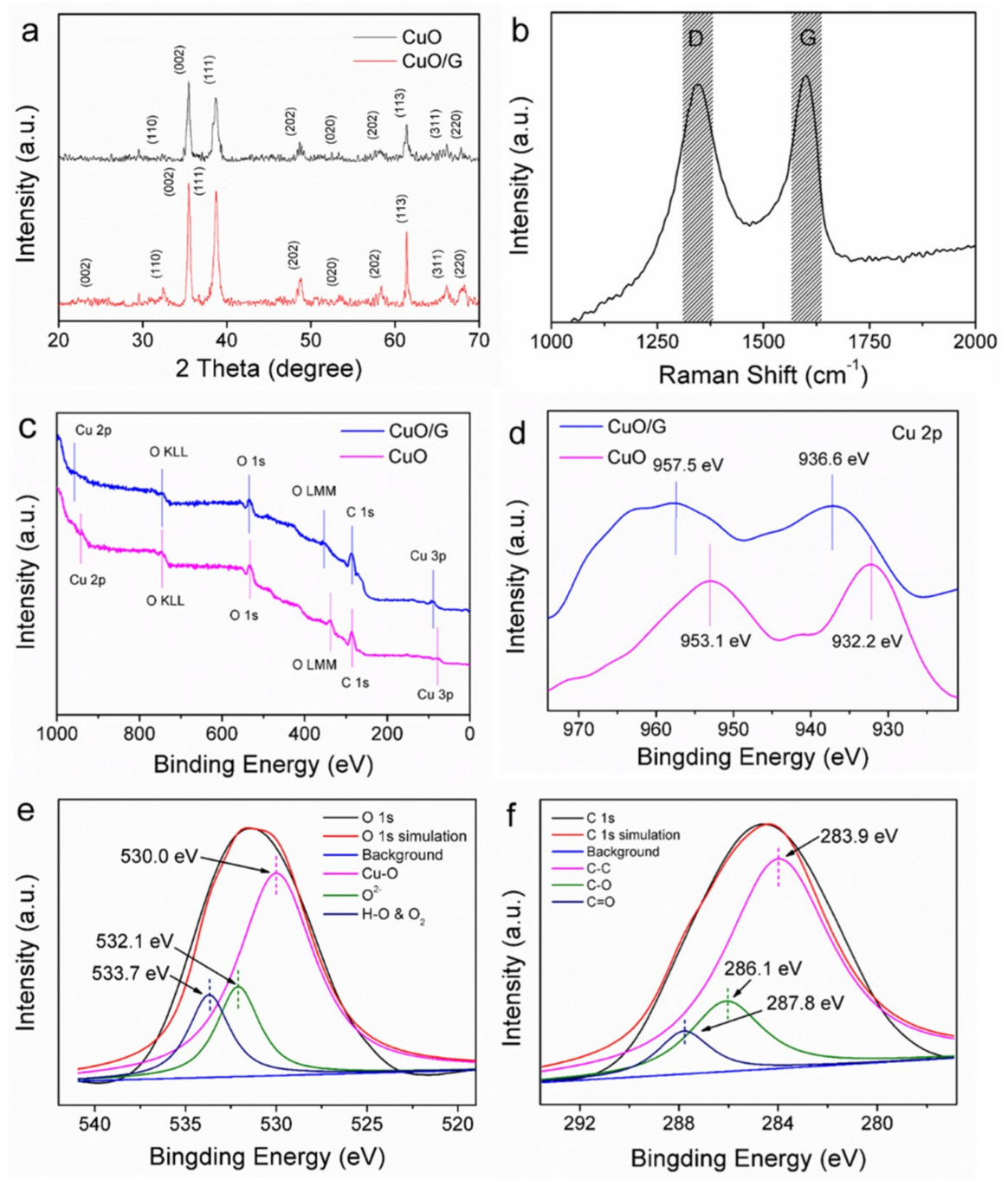

Figure 2. (a) X-ray diffraction patterns of $\mathrm{CuO}$ and $\mathrm{CuO} / \mathrm{G}$. (b) Raman spectrum of $\mathrm{CuO} / \mathrm{G}$. (c) XPS survey spectra of $\mathrm{CuO}$ and $\mathrm{CuO} / \mathrm{G}$, (d) $\mathrm{Cu} 2 \mathrm{p}$ spectra of $\mathrm{CuO}$ and $\mathrm{CuO} / \mathrm{G}, \mathrm{O} 1 \mathrm{~s}(\mathbf{e})$ and $\mathrm{C} 1 \mathrm{~s}(\mathbf{f})$ spectra of $\mathrm{CuO} / \mathrm{G}$. 
Figure 3a-d show the $\mathrm{CVs}$ of $\mathrm{G}, \mathrm{CuO}$ and $\mathrm{CuO} / \mathrm{G}$ in $\mathrm{Ar}$ and then in $\mathrm{O}_{2}$-saturated $0.1 \mathrm{M} \mathrm{KOH}$ from 1.2 to $0.2 \mathrm{~V}$ at a scan rate of $5 \mathrm{mV} / \mathrm{s}$ vs. RHE reference electrode. It can be seen in Figure $3 \mathrm{a}-\mathrm{c}$ that the $\mathrm{CV}$ tests of $\mathrm{G}, \mathrm{CuO}$, and $\mathrm{CuO} / \mathrm{G}$ are essentially featureless under Ar atmosphere in the working potential range. The same phenomenon is also revealed at the $\mathrm{G}$ electrode in $\mathrm{O}_{2}$-saturated electrolyte, indicating that graphene is inherently electrochemically silent in this condition. As shown in Figure $3 b, c, C u O$ and $\mathrm{CuO} / \mathrm{G}$ electrodes display a significant oxygen reduction peak in $\mathrm{O}_{2}$ atmosphere. According to the Pourbaix Diagrams of $\mathrm{Cu}-\mathrm{H}_{2} \mathrm{O}$ system (Figure S1), the dominant species are $\mathrm{Cu}_{2} \mathrm{O}$ and $\mathrm{CuO}$ at $\mathrm{pH}$ around 13 with the potential rang of 1.2 0.2. While in our experiment conditions, the main specie is $\mathrm{CuO}$. When the electrode was stabilized in $0.1 \mathrm{M} \mathrm{KOH}$ solution saturated with $\mathrm{Ar}$, the redox peak due to $\mathrm{Cu}(\mathrm{I}) / \mathrm{Cu}(\mathrm{II})$ should be revealed in the anodic sweep, as indicated in Equation (1). However, there is no obvious redox peaks observed in Figure 3b, which may ascribing to the weak current density of this process that couldn't be detected under this condition:

$$
\mathrm{Cu}_{2} \mathrm{O}+2 \mathrm{OH} \rightarrow 2 \mathrm{CuO}+\mathrm{H}_{2} \mathrm{O}+2 \mathrm{e}^{-}
$$

The ORR activity of the three electrodes increases as follows: $\mathrm{G}<\mathrm{CuO}<\mathrm{CuO} / \mathrm{G}$, as clearly evidenced by the onset potential shown in Figure $3 \mathrm{~d}$. The onset potential of $\mathrm{CuO} / \mathrm{G}$ is comparable to that of $\mathrm{Cu}_{x} \mathrm{Co}_{3-x} \mathrm{O}_{4}[22,23]$ and $\mathrm{Cu} / \mathrm{rGO}$ [24]. The results above demonstrate that graphene can strongly boost the electrocatalytic activity of $\mathrm{CuONPs}$ although it has no catalytic activity alone $[26,33]$. However, the peak current intensities of $\mathrm{CuO} / \mathrm{G}$ is lower than that of $\mathrm{Cu}_{\mathrm{x}} \mathrm{Co}_{3-\mathrm{x}} \mathrm{O}_{4}, \mathrm{Cu} / \mathrm{rGO}$, and commercial $\mathrm{Pt} / \mathrm{C}$ catalyst [34], which should be attributed to the slightly aggregation of the CuO NPs that decreased the numbers of activity center for ORR. The diffusion-current-corrected Tafel plot of specific ORR activity of $\mathrm{CuO}$ and $\mathrm{CuO} / \mathrm{G}$ are show in Figure 3e. The Tafel slope are 207 and $141 \mathrm{mv} / \mathrm{dec}$ for $\mathrm{CuO}$ and $\mathrm{CuO} / \mathrm{G}$, respectively. The Tafel slope of $\mathrm{CuO} / \mathrm{G}$ is smaller than that of $\mathrm{CuO}$, the lower Tafel slope indicates the higher intrinsic catalytic activity [29]. To construct the Tafel plots, the exchange current density is derived from the mass-transport correction using Equation (2) (Supporting Information).

As shown in Table 2, the exchange current density of ORR is $2.12 \times 10^{-8}$ for $\mathrm{CuO}$ and $3.79 \times$ $10^{-5} \mathrm{~mA} / \mathrm{cm}^{2}$ for $\mathrm{CuO} / \mathrm{G}$, and the value of $\mathrm{CuO} / \mathrm{G}$ is approximate to the commercial $\mathrm{Pt} / \mathrm{C}$ which the ORR exchange current density is about $10^{-6}-10^{-9} \mathrm{~mA} \mathrm{~cm}^{-2}$ [34]. It also clearly shows that the $i_{0}$ of $\mathrm{CuO} / \mathrm{G}$ is higher than that of $\mathrm{CuO}$, which can be explained by the synergistic contributions between $\mathrm{CuO}$ NPs and $\mathrm{G}$ sheets. It is clearly seen in Figure $1 \mathrm{~b}$,e that $\mathrm{CuO}$ nanoparticles are densely anchored on the $\mathrm{G}$ single layer which is very important, because this ensures the efficient electron collection via the rGO sheets during the ORR processes. Figure $3 \mathrm{f}$ shows the EIS of $\mathrm{CuO}$ and $\mathrm{CuO} / \mathrm{G}$. It is obvious that the resistance of $\mathrm{CuO} / \mathrm{G}$ electrode is smaller than that of $\mathrm{CuO}$, owing to the conductive $\mathrm{G}$ nanosheets improve the electron transfer in $\mathrm{CuO} / \mathrm{G}$ materials. The fitted equivalent circuit of $\mathrm{CuO} / \mathrm{G}$ is shown in Figure 3g, the obtained Rs1, Rs2, Rp1 and Rp2 are 1128, 100, 1303, and $6571 \Omega$, respectively. Figure $3 \mathrm{~h}$ shows the long-term stability of the $\mathrm{CuO}$ and $\mathrm{CuO} / \mathrm{G}$ electrode, by running the ORR for 16,000 s at a fixed potential. The test of commercial $\mathrm{Pt} / \mathrm{C}$ is also evaluated for comparison. The data collected suggests a high stability of $\mathrm{CuO}$ and $\mathrm{CuO} / \mathrm{G}$ with a slight performance attenuation after 16,000 s of operation, while commercial $\mathrm{Pt} / \mathrm{C}$ shows a gradual degradation. This confirms the strong interactions between the $\mathrm{CuO}$ NPs and the graphene, which preventing active sites from losing during cycling [24].

Table 2. Calculated value of $i_{0}$ for $\mathrm{CuO}$ and $\mathrm{CuO} / \mathrm{G}$.

\begin{tabular}{ccc}
\hline Sample & CuO & CuO/G \\
\hline$i_{0}\left(\mathrm{~mA} / \mathrm{cm}^{2}\right)$ & $2.12 \times 10^{-8}$ & $3.79 \times 10^{-5}$ \\
\hline
\end{tabular}

Figure 4a shows the polarization curves of $\mathrm{CuO}$ nanohybrid at different rotation rates. All the curves reach well-defined diffusion limiting currents. In order to quantitatively understand the ORR activity of $\mathrm{CuO}$ electrode, the $K-L$ plots at different rotating rates are analyzed (Figure $4 \mathrm{~b}$ ). As can be seen, all the $K-L$ plots display good linearity. According to $K-L$ equations (Equations (3) 
and (4)) (Supporting Information), the electron transfer number (n) for per oxygen molecule can be estimated from the intercepts and slopes. The result reveals that the $\mathrm{n}$ of $\mathrm{CuO}$ calculated from the B-factor is ranges from 3.18 to 3.35 [35]. Similar profiles can be also seen from the $\mathrm{CuO} / \mathrm{G}$ catalyst, as shown in Figure 4c,d, the calculated electron transfer number is in the range of 3.84 3.92, indicating a four-electron mechanistic pathway, which is similar to the previous studies of Gewirth and Wang et al. [21,36]. However, the ORR catalyzed by individual copper oxide behave in a mixed mechanistic fashion operating with two- and four-electrons [37]. As has been reported that depending on the metal-graphene spacing and the spinel structure of transition metal oxides, charge transfer may exist between the transition metal oxides and graphene, which may be the real reason that certain transition metal oxides NPs supported on graphene surface exhibit enhanced catalytic activities [38].
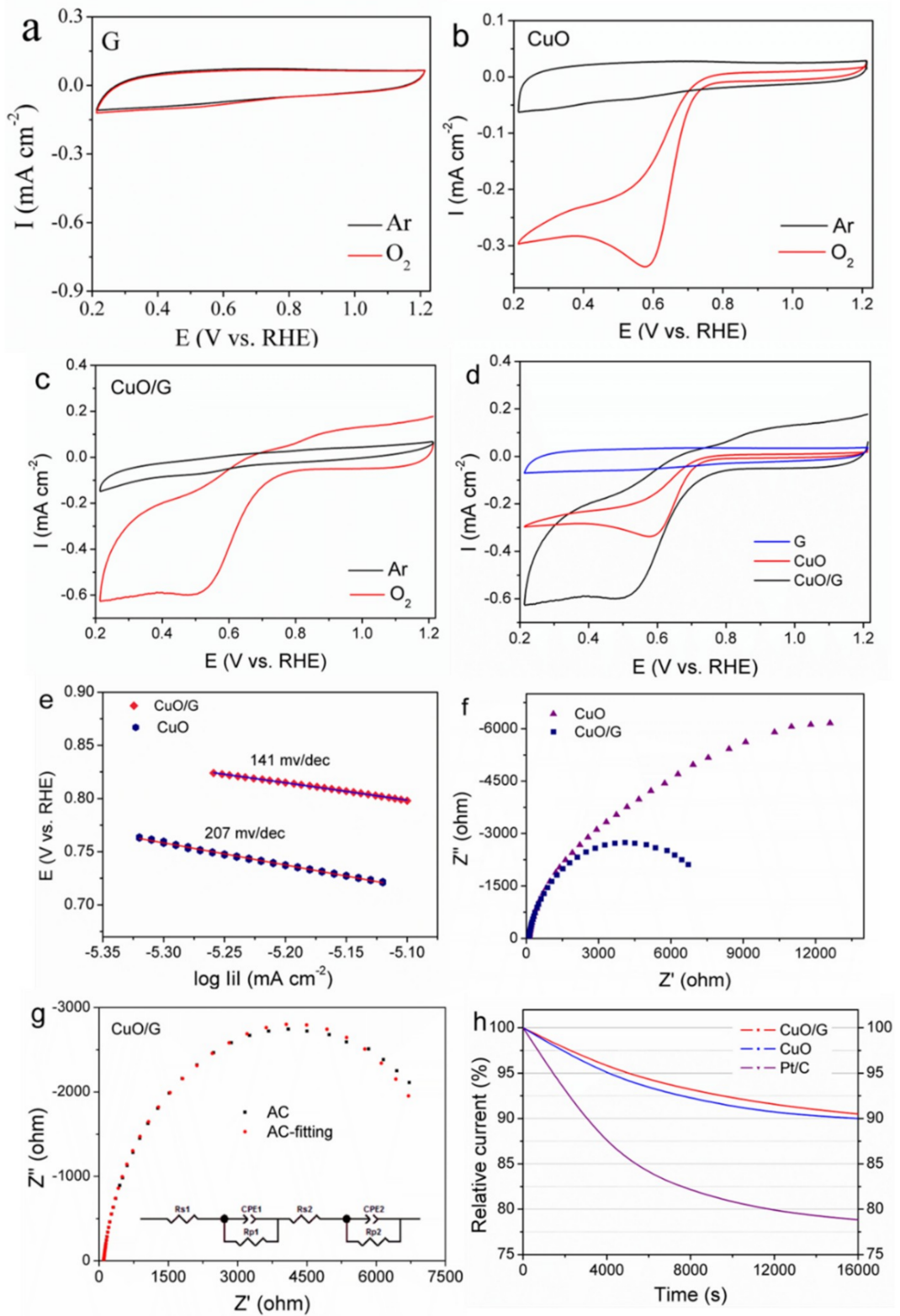

Figure 3. $\mathrm{CVs}$ of (a) $\mathrm{G},(\mathbf{b}) \mathrm{CuO}$ and (c) $\mathrm{CuO} / \mathrm{G}$ in $\mathrm{Ar}$ and $\mathrm{O}_{2}$-saturated $0.1 \mathrm{~mol} / \mathrm{L} \mathrm{KOH}$ at $25{ }^{\circ} \mathrm{C}$. (d) Comparation of $\mathrm{CV}$ tests of $\mathrm{G}, \mathrm{CuO}$ and $\mathrm{CuO} / \mathrm{G}$ in $\mathrm{O}_{2}$-saturated $0.1 \mathrm{M} \mathrm{KOH}$. Scan rate: $5 \mathrm{mV} / \mathrm{s}$. (e) Tafel plots and (f) comparison of nyquist plots during ORR on $\mathrm{CuO}$ and $\mathrm{CuO} / \mathrm{G}$. (g) Modulated equivalent circuit of nyquist plot on $\mathrm{CuO} / \mathrm{G}$. (h) Chronoamperometry of $\mathrm{CuO}, \mathrm{CuO} / \mathrm{G}$ and commercial $\mathrm{Pt} / \mathrm{C}$ catalyst at $-0.65 \mathrm{~V}$ for $16,000 \mathrm{~s}$. 

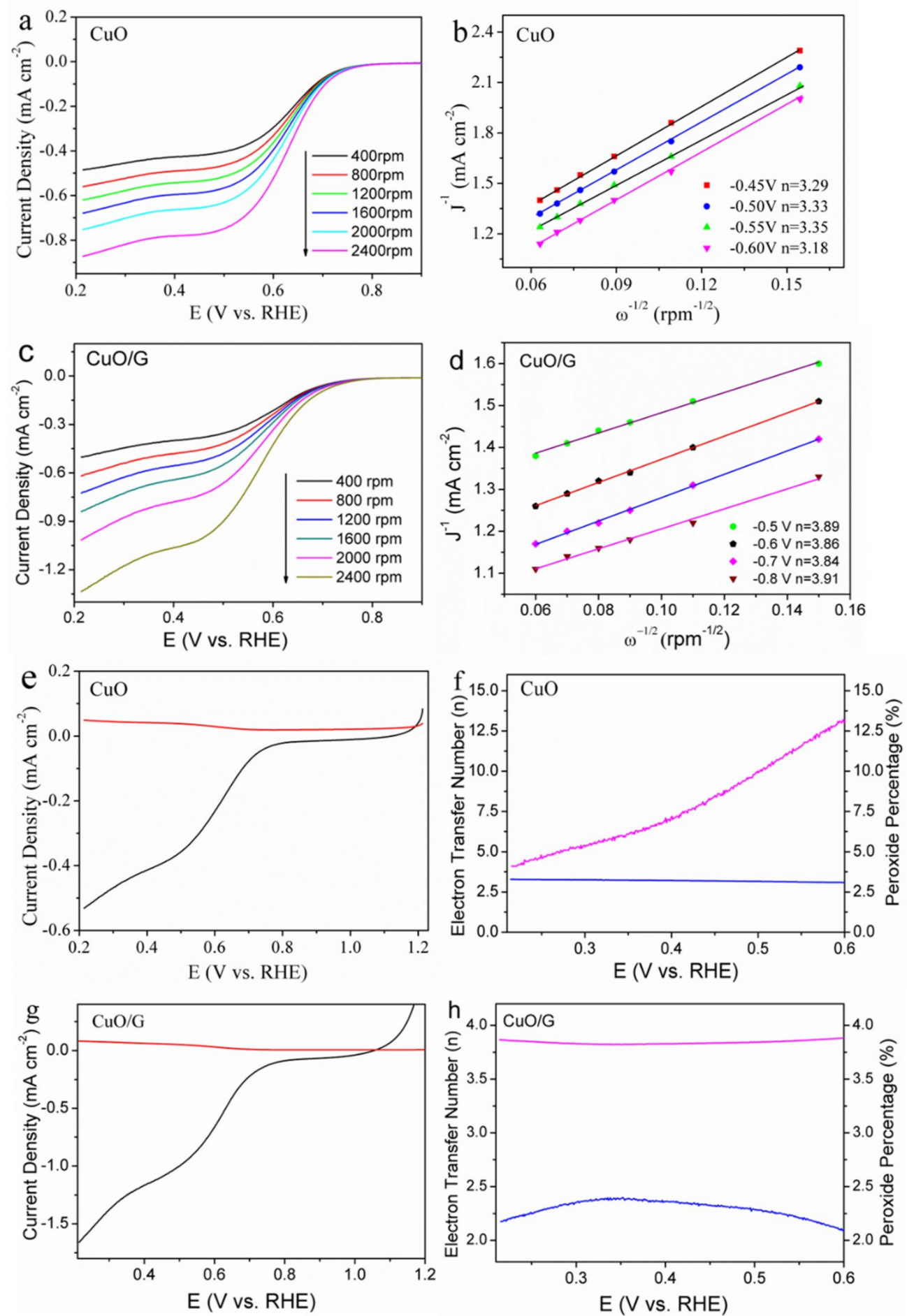

Figure 4. Investigating of ORR mechanism on catalysts: (a and c) rotating disk LSV profiles of CuO and $\mathrm{CuO} / \mathrm{G}$, respectively in $\mathrm{O}_{2}$-saturated $0.1 \mathrm{M} \mathrm{KOH}$ solution at various rotation rates ranging from 400 to $2400 \mathrm{rpm}$ along with (b and d) their corresponding Koutecky-Levich plots at different potentials. Rotating ring disk electrode (RRDE) LSV profiles (e and g) on $\mathrm{CuO}$ and $\mathrm{CuO} / \mathrm{G}$ at a rotation rate of $1600 \mathrm{rpm}$ along with their percentage of peroxides and the electron transfer number $(\mathbf{f}$ and $\mathbf{h})$, scan rate: $5 \mathrm{mV} / \mathrm{s}$. 
According to the Pourbaix Diagrams of $\mathrm{O}_{2}-\mathrm{H}_{2} \mathrm{O}$ system, the ORR can happen through a four-electron or two-electron process at $\mathrm{pH}$ around 13 with the potential rang of 1.2 0.2:

$$
\begin{gathered}
\mathrm{O}_{2}+2 \mathrm{H}_{2} \mathrm{O}+4 \mathrm{e}^{-} \rightarrow 4 \mathrm{OH}^{-} \\
\mathrm{O}_{2}+2 \mathrm{H}_{2} \mathrm{O}+2 \mathrm{e}^{-} \rightarrow 2 \mathrm{OH}^{-}+\mathrm{H}_{2} \mathrm{O}_{2} \\
\mathrm{H}_{2} \mathrm{O}_{2}+2 \mathrm{e}^{-} \rightarrow 2 \mathrm{OH}^{-}
\end{gathered}
$$

In order to further probe the ORR mechanism taking place on the two electrodes simply and exactly, rotating ring-disk electrode (RRDE) were performed to monitor the electron transfer number and the formation of hydrogen peroxide $\left(\mathrm{H}_{2} \mathrm{O}_{2}\right)$ during the ORR process, in $\mathrm{O}_{2}$-saturated $0.1 \mathrm{M} \mathrm{KOH}$ solution with a scan rate of $5 \mathrm{mV} / \mathrm{s}$ at $1600 \mathrm{rpm}$. As shown in Figure 4e,g, CuO/G exhibits higher disk current and lower ring current (peroxide oxidation), compared with $\mathrm{CuO}$ catalyst. Based on rotating ring-disk voltammograms, the electron transfer number and the current efficiency for hydrogen peroxide formation $\left(\mathrm{H}_{2} \mathrm{O}_{2} \%\right)$ during the ORR process are determined quantitatively according to Equation (5) and (6) (Supporting Information). As can be seen in Figure $4 \mathrm{f}$, the measured $\mathrm{H}_{2} \mathrm{O}_{2}$ yield of $\mathrm{CuO}$ catalyst is lower than $14 \%$. Specifically, the average transferred electron number is found to vary between 3.1 and 3.4, indicating that ORR at the $\mathrm{CuO}$ electrode proceeds via both two-electron and four-electron pathways. While, seen in Figure $4 \mathrm{~h}$, the $\mathrm{H}_{2} \mathrm{O}_{2}$ yield of $\mathrm{CuO} / \mathrm{G}$ is less than $2.5 \%$, accordingly, the electron transfer number is found to vary between 3.8 and 4.0. These results suggest that the ORR catalyzed by $\mathrm{CuO} / \mathrm{G}$ is mainly through a four-electron pathway by directly forming hydroxyl species as the final products.

\section{Experimental}

\section{Sample Preparation}

Graphene oxide (GO) sheets were prepared by a modified Hummers method in our laboratory [36,39]. The $\mathrm{CuO} / \mathrm{G}$ is synthesized by a one pot solvothermal method as illustrated in Scheme 1. $1.70 \mathrm{~g}$ copper chloride $\left(\mathrm{CuCl}_{2} \cdot 2 \mathrm{H}_{2} \mathrm{O}\right)$ was first dispersed into $40 \mathrm{~mL}$ deionized water, followed by the addition of $6 \mathrm{~mL} \mathrm{GO}(6 \mathrm{~g} / \mathrm{L})$ and $1.60 \mathrm{~g}$ sodium hydroxide. After magnetic stirring for $10 \mathrm{~min}, 50 \mathrm{~mL}$ absolute ethyl alcohol and $2 \mathrm{~mL}$ ethylene glycol were added into the solution. The obtained solution was removed to a teflon centrality that sealed by stainless cylinder and kept at $180^{\circ} \mathrm{C}$ for $24 \mathrm{~h}$. After naturally cooling down, the precipitates were collected, and thoroughly washed with ethanol and deionized water. Finally, the obtained powder was dried at $60-80{ }^{\circ} \mathrm{C}$ in vacuum for characterization. Then $0.79 \mathrm{~g} \mathrm{CuO} / \mathrm{G}$ was obtained, and the yield of reaction was calculated to be about $95 \%$. Moreover, the samples without $\mathrm{CuO}$ or $\mathrm{G}$ were also synthesized for comparison under the same condition, and were denoted as $\mathrm{G}$ and $\mathrm{CuO}$.

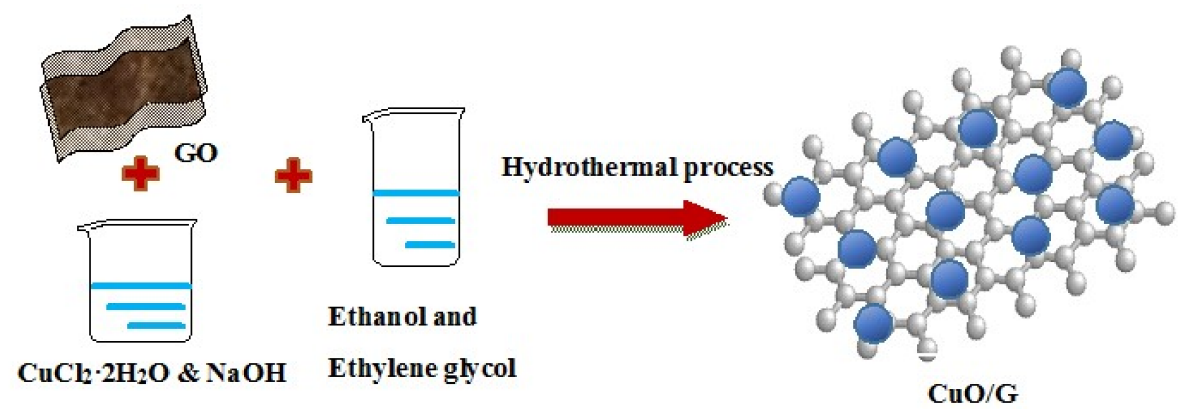

Scheme 1. Synthesis procedure of $\mathrm{CuO} / \mathrm{G}$ hybrid. 


\section{Conclusions}

We have demonstrated a facile route to fabricate $\mathrm{CuO} / \mathrm{G}$ hybrid. Due to the enhanced kinetics for electron transfer resulting from its unique structure of $\mathrm{CuO}$ NPs dispersed on conductive graphene layers, the $\mathrm{CuO} / \mathrm{G}$ electrode exhibits excellent electrocatalytic performance, in terms of high cathodic current density, positive onset potential, and a high electron transfer number for ORR in $0.1 \mathrm{M} \mathrm{KOH}$ solution. The electron transfer numbers for the ORR on the $\mathrm{CuO} / \mathrm{G}$ electrode is calculated to be about 3.9 , indicating a four-electron mechanistic pathway from $\mathrm{O}_{2}$ to $\mathrm{OH}^{-}$. In addition, the $\mathrm{CuO} / \mathrm{G}$ electrode also shows superior fuel durability compared to the commercial $\mathrm{Pt} / \mathrm{C}$ catalyst after a long-term operation of $16,000 \mathrm{~s}$. Thus, it is expected that the $\mathrm{CuO} / \mathrm{G}$ hybrid could have a great potential as a non-precious metal-based catalyst towards the ORR.

Supplementary Materials: The supplementary materials are available online.

Author Contributions: Writing—original draft preparation, J.Y.; Writing—review and editing, J.Y., T.H., Z.J., M.S. and C.T.

Funding: Financial support for this work was provided by a project of the Shandong Province Higher Educational Science and Technology Program (J17KA094), the Scientific Research Fund of the University of Jinan (XBS1644), the Science Development Project of Shandong Province (2017GGX40115 and 2016GGX102038), and the Shandong Natural Science Foundation (nos. ZR2017QB009 and ZR2018MB036).

Conflicts of Interest: The authors declare no conflicts of interest. The funders had no role in the design of the study; in the collection, analyses, or interpretation of data; in the writing of the manuscript, or in the decision to publish the results.

\section{References}

1. Xu, Y.; Xu, R. Nickel-based cocatalysts for photocatalytic hydrogen production. Appl. Surf. Sci. 2015, 351, 779-793. [CrossRef]

2. Chatterjee, K.; Ashokkumar, M.; Gullapalli, H.; Gong, Y.; Vajtai, R.; Thanikaivelan, P.; Ajayan, P.M. Nitrogen-rich carbon nano-onions for oxygen reduction reaction. Carbon 2018, 130, 645-651. [CrossRef]

3. Grove, W.R.; Esq. M.A. XXIV. On voltaic series and the combination of gases by platinum. Philos. Mag. 1966, 14, 127-130.

4. Nasini, U.B.; Gopal, V.; Bairi; Kumar, S.; Ramasahayam; Bourdo, S.E.; Viswanathan, T.; Shaikh, A.U. Oxygen Reduction Reaction Studies of Phosphorus and Nitrogen Co-Doped Mesoporous Carbon Synthesized via Microwave Technique. Chemelectrochem 2014, 1, 573-579. [CrossRef]

5. Awad, M.I.; Ohsaka, T. An electrocatalytic oxygen reduction by copper nanoparticles-modified Au(100)-rich polycrystalline gold electrode in 0.5 M KOH. J. Power Sources 2013, 226, 306-312. [CrossRef]

6. Wang, Y.Z.; Shao, X.; Xu, H.Y.; Xie, M.; Deng, S.X.; Wang, H.; Liu, J.B.; Yan, H. Facile synthesis of porous $\mathrm{LiMn}_{2} \mathrm{O}_{4}$ spheres as cathode materials for high-power lithium ion batteries. J. Power Sources 2013, 226, 140-148. [CrossRef]

7. Neburchilov, V.; Wang, H.; Martin, J.J.; Wei, Q. A review on air cathodes for zinc-air fuel cells. J. Power Sources 2010, 195, 1271-1291. [CrossRef]

8. Bruce, P.G.; Hardwick, L.J.; Abraham, K.M. Lithium-air and lithium-sulfur batteries. Mrs. Bull. 2011, 36, 506-512. [CrossRef]

9. Jia, Q.; Zhao, Z.; Cao, L.; Li, J.; Ghoshal, S.; Davies, V.; Stavitski, E.; Attenkofer, K.; Liu, Z.; Li, M.; et al. Roles of Mo Surface Dopants in Enhancing the ORR Performance of Octahedral PtNi Nanoparticles. Nano Lett. 2018, 18, 798-804. [CrossRef]

10. Chen, A.; Ostrom, C. Palladium-Based Nanomaterials: Synthesis and Electrochemical Applications. Chem. Rev. 2015, 115, 11999-12044. [CrossRef]

11. Lefevre, M.; Proietti, E.; Jaouen, F.; Dodelet, J.P.; Hay, A.S. Catalyst Precursors, Catalysts and Methods of Producing Same. U.S. Patent 8580704B2, 12 December 2013.

12. Xue, Y.; Yu, D.; Dai, L.; Wang, R.; Li, D.; Roy, A.; Lu, F.; Chen, H.; Liu, Y.; Qu, J. Three-dimensional B,N-doped graphene foam as a metal-free catalyst for oxygen reduction reaction. Phys. Chem. Chem. Phys. PCCP 2013, 15, 12220-12226. [CrossRef] 
13. Li, Y.; Zhou, W.; Wang, H.; Xie, L.; Liang, Y.; Wei, F.; Idrobo, J.C.; Pennycook, S.J.; Dai, H. An oxygen reduction electrocatalyst based on carbon nanotube-graphene complexes. Nat. Nanotechnol. 2012, 7, 394-400. [CrossRef]

14. Proietti, E.; Jaouen, F.; Lefèvre, M.; Larouche, N.; Tian, J.; Herranz, J.; Dodelet, J.P. Iron-based cathode catalyst with enhanced power density in polymer electrolyte membrane fuel cells. Nat. Commun. 2011, 2, 416. [CrossRef]

15. Liang, Y.; Wang, H.; Zhou, J.; Li, Y.; Wang, J.; Regier, T.; Dai, H. Covalent hybrid of spinel manganese-cobalt oxide and graphene as advanced oxygen reduction electrocatalysts. J. Am. Chem. Soc. 2012, 134, 3517-3523. [CrossRef]

16. Takashima, T.; Hashimoto, K.; Nakamura, R. Inhibition of charge disproportionation of $\mathrm{MnO}_{2}$ electrocatalysts for efficient water oxidation under neutral conditions. J. Am. Chem. Soc. 2012, 134, 18153-18156. [CrossRef]

17. Hossen, M.M.; Artyushkova, K.; Atanassov, P.; Serov, A. Synthesis and characterization of high performing Fe-N-C catalyst for oxygen reduction reaction (ORR) in Alkaline Exchange Membrane Fuel Cells. J. Power Sources 2018, 375, 214-221. [CrossRef]

18. Zhou, R.; Zheng, Y.; Hulicovajurcakova, D.; Qiao, S.Z. Enhanced electrochemical catalytic activity by copper oxide grown on nitrogen-doped reduced graphene oxide. J. Mater. Chem. A 2013, 1, 13179-13185. [CrossRef]

19. Jahan, M.; Liu, Z.; Loh, K.P. A Graphene Oxide and Copper-Centered Metal Organic Framework Composite as a Tri-Functional Catalyst for HER, OER, and ORR. Adv. Funct. Mater. 2013, 23, 5363-5372. [CrossRef]

20. Gewirth, A.A.; Thorum, M.S. Electroreduction of dioxygen for fuel-cell applications: Materials and challenges. Inorg. Chem. 2010, 49, 3557-3566. [CrossRef]

21. Wang, J.; Wang, K.; Wang, F.B.; Xia, X.H. Bioinspired copper catalyst effective for both reduction and evolution of oxygen. Nat. Commun. 2014, 5, 5285. [CrossRef]

22. Koninck, M.D.; Poirier, S.C.; Marsan, B. CuxCo3-xO4 used as bifunctional electrocatalyst. J. Electrochem. Soc. 2006, 153, A2103-A2110. [CrossRef]

23. Koninck, M.D.; Poirier, S.C.; Marsan, B. $\mathrm{Cu}_{\mathrm{x}} \mathrm{Co}_{3}-\mathrm{xO}_{4}$ Used as Bifunctional Electrocatalyst II. Electrochemical Characterization for the Oxygen Reduction Reaction. J. Electrochem. Soc. 2007, 154, A381-A388.

24. Ania, C.O.; Seredych, M.; Rodriguez-Castellon, E.; Bandosz, T.J. New copper/GO based material as an efficient oxygen reduction catalyst in an alkaline medium: The role of unique $\mathrm{Cu} / \mathrm{rGO}$ architecture. Appl. Catal. B Environ. 2015, 163, 424-435. [CrossRef]

25. Blanford, C.F.; Heath, R.S.; Armstrong, F.A. A stable electrode for high-potential, electrocatalytic $\mathrm{O}(2)$ reduction based on rational attachment of a blue copper oxidase to a graphite surface. Chem. Commun. 2007, 2007, 1710-1712. [CrossRef]

26. Tian, Y.; Liu, Y.; Wang, W.-p.; Zhang, X.; Peng, W. CuO nanoparticles on sulfur-doped graphene for nonenzymatic glucose sensing. Electrochim Acta 2015, 156, 244-251. [CrossRef]

27. Sherly, E.D.; Vijaya, J.J.; Kennedy, L.J. Visible-light-induced photocatalytic performances of ZnO-CuO nanocomposites for degradation of 2,4-dichlorophenol. Chin. J. Catal. 2015, 36, 1263-1272. [CrossRef]

28. Ferrari, A.C.; Meyer, J.C.; Scardaci, V.; Casiraghi, C.; Lazzeri, M.; Mauri, F.; Piscanec, S.; Jiang, D.; Novoselov, K.S.; Roth, S. The Raman Fingerprint of Graphene. 2006. [CrossRef]

29. Bian, W.; Yang, Z.; Strasser, P.; Yang, R. A CoFe $\mathrm{O}_{4}$ /graphene nanohybrid as an efficient bi-functional electrocatalyst for oxygen reduction and oxygen evolution. J. Power Sources 2014, 250, 196-203. [CrossRef]

30. Hong, Y.; Tian, C.; Jiang, B.; Wu, A.; Zhang, Q.; Tian, G.; Fu, H. Facile synthesis of sheet-like ZnO assembly composed of small ZnO particles for highly efficient photocatalysis. J. Mater. Chem. A 2013, 1, 5700-5708. [CrossRef]

31. Li, S.S.; Lv, J.J.; Hu, Y.Y.; Zheng, J.N.; Chen, J.R.; Wang, A.J.; Feng, J.J. Facile synthesis of porous Pt-Pd nanospheres supported on reduced graphene oxide nanosheets for enhanced methanol electrooxidation. J. Power Sources 2014, 247, 213-218. [CrossRef]

32. Li, S.S.; Wang, A.J.; Hu, Y.Y.; Fang, K.M.; Chen, J.R.; Feng, J.J. One-step, seedless wet-chemical synthesis of gold@palladium nanoflowers supported on reduced graphene oxide with enhanced electrocatalytic properties. J. Mater. Chem. A 2014, 2, 18177-18183. [CrossRef]

33. Du, C.; Gao, X.; Chen, W. Recent developments in copper-based, non-noble metal electrocatalysts for the oxygen reduction reaction. Chinese J. Catal. 2016, 37, 1049-1061. [CrossRef] 
34. Hung, T.F.; Bei, W.; Tsai, C.W.; Tu, M.H.; Wang, G.X.; Liu, R.S.; Tsai, D.P.; Lo, M.Y.; Shy, D.S.; Xing, X.K. Sulfonation of graphene nanosheet-supported platinum via a simple thermal-treatment toward its oxygen reduction activity in acid medium. Int. J. Hydrogen Energy 2012, 37, 14205-14210. [CrossRef]

35. Zhou, J.; Xiao, H.; Zhou, B.; Huang, F.; Zhou, S.; Xiao, W.; Wang, D. Hierarchical MoS ${ }_{2}-$ rGO nanosheets with high $\mathrm{MoS}_{2}$ loading with enhanced electro-catalytic performance. Appl. Surf. Sci. 2015, 358, 152-158. [CrossRef]

36. Wang, G.; Shen, X.; Wang, B.; Yao, J.; Park, J. Synthesis and characterisation of hydrophilic and organophilic graphene nanosheets. Carbon 2009, 47, 1359-1364. [CrossRef]

37. Pendashteh, A.; Palma, J.; Anderson, M.; Marcilla, R. NiCoMnO 4 nanoparticles on N-doped graphene: Highly efficient bifunctional electrocatalyst for oxygen reduction/evolution reactions. Appl. Catal. B Environ. 2017, 201, 241-252. [CrossRef]

38. Yan, Z.; Qi, H.; Bai, X.; Huang, K.; Chen, Y.-R.; Wang, Q. Mn doping of cobalt oxynitride coupled with N-rGO nanosheets hybrid as a highly efficient electrocatalyst for oxygen reduction and oxygen evolution reaction. Electrochim. Acta 2018, 283, 548-559. [CrossRef]

39. Hu, J.; Zhang, F. Self-assembled fabrication and flame-retardant properties of reduced graphene oxide/waterborne polyurethane nanocomposites. J. Therm. Anal. Calorim. 2014, 118, 1561-1568. [CrossRef]

Sample Availability: Samples of the compounds are available from the authors. 